\title{
Editorial
}

\section{Semeando em meio à tempestade}

O Brasil atravessa o que talvez seja o momento mais grave de sua história, pois enfrenta uma crise sanitária mundial em meio a uma trágica crise econômica e política.

A partir do golpe jurídico-parlamentar de 2016, houve um sensível aprofundamento do desrespeito aos direitos mais elementares das trabalhadoras e trabalhadores. Esses direitos vêm sendo pilhados por agentes de um projeto ultra neoliberal, implementado por um governo de extrema direita, que viola todas as garantias constitucionais ainda existentes.

A falácia de que as "reformas" trabalhista e da previdência, a terceirização ilimitada, os cortes orçamentários em gastos sociais, a política de privilégios aos bancos, dentre outras, levariam à recuperação econômica, repetida desde antes da pandemia, revelase com nitidez através do aumento do desemprego e da ampliação da desigualdade.

A pandemia da COVID 19 encontrou ainda mais fragilizadas as trabalhadoras e trabalhadores e as mais amplas parcelas empobrecidas da população brasileira. $\mathrm{O}$ governo Bolsonaro mostrou que não tem compromisso com o povo brasileiro e com a classe trabalhadora. Já havia fechado as portas do Ministério do Trabalho e agora nem Ministério da Saúde ou da Educação temos. Não há qualquer demonstração de interesse ou competência em proteger a população brasileira, ante o avanço avassalador do vírus - e já são muitas dezenas de milhares de mortos e milhões de infectados.

O Instituto Trabalho Digno, que tem nova diretoria desde maio de 2020, continua seu propósito de defender a proteção ao trabalho e tem juntado sua voz ao coro dos que 
repudiam a destruição de direitos das trabalhadoras e dos trabalhadores. Do mesmo modo, a Laborare, agora contando com a Juíza e Professora Valdete Souto Severo como coeditora, segue estimulando reflexões sobre a reconstrução dos direitos e a defesa do trabalho digno.

Nesta edição, o Professor Ricardo Antunes questiona sobre o Futuro do Trabalho na Era Digital e sobre a necessidade de florescimento de uma subjetividade autêntica e emancipada, dando um novo sentido ao trabalho e à humanidade.

O pesquisador Leo Liberato, da Fundacentro, reflete sobre o paradigma ou modelo de concepção de riscos e de prevenção em Segurança e Saúde no Trabalho, confrontando as campanhas de sindicatos dos(as) trabalhadores(as) com as patrocinadas por entidades empresariais.

Claudio Jannotti da Rocha indaga se o trabalho contemporâneo é capaz de libertar-se e sobre quais são as condições necessárias para se assegurar o exercício concreto do direito fundamental ao trabalho digno.

Ao abordar a fiscalização dos contratos administrativos nos contratos terceirizados no setor público, Tom Lima Vasconcelos aponta para a responsabilidade de todos os entes envolvidos, mais ainda em um cenário de recrudescimento da racionalidade neoliberal.

Os acadêmicos de Direito da UFBA Bianca Silva Matos, Gabriel Trajano Azevedo Moreira dos Santos e Tâmara Brito de França, somaram-se à Professora Renata Queiroz Dutra, agora professora da Universidade de Brasília, para revisar a bibliografia relativa ao direito fundamental ao trabalho digno, analisando o contrato intermitente de trabalho à luz da Constituição.

Ao apresentar mais essa edição da nossa Revista, reafirmamos nosso compromisso com a discussão acadêmica séria e crítica, acerca do mundo do trabalho e das 
Editorial: Semeando em meio à tempestade

questões que envolvem saúde e segurança das pessoas que vivem do trabalho em nosso país.

Os tantos desafios que nos convocam nesses tempos estranhos apenas reforçam nosso ânimo de estudo e de troca. Seguimos nosso caminho acreditando que é possível construir um Mundo do Trabalho Digno.

Continuaremos a semear em plena tempestade porque acreditamos que nosso país tem potencial para ser, realmente, uma sociedade fraterna e solidária, sem tanta desigualdade e com garantia de condições materiais de existência, o que significa possibilidade efetiva de exercício dos direitos sociais e da Liberdade.

\section{Os Editores}

